DOI: $10.52950 / T E .2021 .9 .1 .003$

\title{
A JUST WAGE: SOCIAL JUSTICE IN THE LABOR MARKET
}

\section{LUKÁŠ AUGUSTIN MÁSLO}

\begin{abstract}
:
The author deals with a question of the just wage, its rationale and practical implementation from the perspective of classical philosophy and Catholic social teaching. In the methodological section, the author argues that because moral and political philosophy stands higher than economics in the hierarchy of sciences, the wage-justice perspective should take precedence over the just-wage perspective. In the section on education, the author calls for a real inter-disciplinarity in education which would eliminate the arrogance of a one-discipline approach and establish a relevant-discipline approach. This paper wants to be an example of such a relevant-discipline approach. The author contends that the term "just wage" can be perceived in two meanings: 1 ) in the meaning of legal or social justice as a family wage; 2 ) in the meaning of commutative justice as a value of the employee's performance which contributes to the production of the total physical product. Where the value of the labor performance cannot be estimated lower than the cost of authentically human living. This paper provides micro- and macroeconomic reasons for the conclusion that the legal minimum wage is not an effective instrument to make an employer pay a just wage and presents the conclusion that the only way to make the employer pay a just wage is a creation of such an institutional environment in which the owners and managers will want to pay just wages on their own, at the expense of their own profit. The author contends that a distributist vision of "restoration of property could provide a functional solution to this. The reason why popes before and during the industrial revolution didn't criticize low incomes of peasants is, according to the author, that the family life and working life were not separated in the institutional environment of the countryside economy which is why the incomes of the peasants allowed the man to fulfill his obligations in relation to his family.
\end{abstract}

\section{Keywords:}

just wage, minimum wage, labor demand, social justice, industrial revolution, Catholic social teaching, laissez-faire, education

JEL Classification: A12, N33, J83

\section{Authors:}

LUKÁŠ AUGUSTIN MÁSLO, Vysoká škola ekonomická v Praze, Czech Republic, Email: lukas.maslo@vse.cz

\section{Citation:}

LUKÁŠ AUGUSTIN MÁSLO (2021). A Just Wage: Social Justice in the Labor Market. International Journal of Teaching and Education, Vol. IX(1), pp. 29-48., 10.52950/TE.2021.9.1.003 


\section{Introduction}

The labourer is worthy of his reward. (1Timothy 5:18)

A worker has a right to his wage. A worker does not have a right to any wage, though, but a just wage. Is a payment of the just wage an act of commutative or distributive justice? ${ }^{1} \mathrm{Next}$, what determines the value of the just wage? Laissez-faire ideology ${ }^{2}$ is clear about this: a just wage is such a wage which is agreed on between the contractual parties. Leo XIII criticizes this attitude sharply in the encyclical Rerum Novarum. The pope does not stick to a criticism only but suggests positively what a just wage is: If a workman's wages be sufficient to enable him comfortably to support himself, his wife, and his children, he will find it easy, if he be a sensible man, to practice thrift, and he will not fail, by cutting down expenses, to put by some little savings and thus secure a modest source of income. (Rerum Novarum, 46.) Pius XI defines a just wage explicitly in his encyclical Quadragesimo Anno: In the first place, the worker must be paid a wage sufficient to support him and his family. [...] It is an intolerable abuse, and to be abolished at all cost, for mothers on account of the father's low wage to be forced to engage in gainful occupations outside the home to the neglect of their proper cares and duties, especially the training of children. Every effort must therefore be made that fathers of families receive a wage large enough to meet ordinary family needs adequately. (Quadragesimo Anno, 71.) In this paper, I will try to find out what kind of justice a payment of the just wage represents. Next, I will look for the answer to a question whether the legal minimum wage is an effective instrument for the employees to get just wages. Next, I will try to provide an explanation why the popes prior to Leo XIII did not criticize unjust wages, despite the real incomes of the vast majority of the Medieval and Modern Christian Europe's population - according to laissez-faire proponents - being lower than at the end of the industrial revolution.

\section{Methodological Questions}

It was John Neville Keynes who drew a distinction between a science and an art on the one hand and a positive science and a normative science on the other hand:

As the terms are here used, a positive science may be defined as a body of systemized knowledge concerning what is; [...] a normative or regulative science as a body of systemized knowledge relating to criteria of what ought to be, and concerning therefore with the ideal as distinguished from the actual; [...] an art as a system of rules for the attainment of a given end. [...] The object of a positive science is the establishment of uniformities, of a normative science the determination of ideals, of an art the formulation of precepts. (Keynes, 1890, p. 22).

Also, it was Keynes who pioneered the concept of economics (or political economy) as a positive science. Currently, there is a general agreement among economists that this is the case. Barely any economist would dare to challenge the opinion that economics is value-free in its nature. This opinion is being presented to students of economics as a fact. Mankiw in his Principles of Economics explains the issue as follows:

\footnotetext{
${ }^{1}$ For a connection between commutative and distributive justice see Worland (1981, p. 296, n. 58); Gordley (1998, p. 12)

2 In Europe, the synonymous term "economic liberalism" can be used.
} 
In general, statements about the world come in two types. One type [...] is positive. Positive statements are descriptive. They make a claim about how the world is. A second type of statement [...] is normative. Normative statements are prescriptive. They make a claim about how the world ought to be. A key difference between positive and normative statements is how we judge their validity. We can, in principle, confirm or refute positive statements by examining evidence. An economist might evaluate [a positive] statement [Minimum-wage laws cause unemployment.] by analyzing data on changes in minimum wages and changes in unemployment over time. By contrast, evaluating normative statements involves values as well as facts. [A normative] statement [The government should raise the minimum wage.] cannot be judged using data alone. Deciding what is good or bad policy is not just a matter of science. It also involves our views on ethics, religion, and political philosophy. (Mankiw, 2015, p. 28).

Holman in his coursebook of intermediate microeconomics puts it forward like this:

$[T]$ he science can examine whether analytical judgements are true or false. It is a feature of analytical judgments that they can be proven empirically. An analytical judgement can be verified or falsified by means of an observation or an experiment. A value judgement cannot be verified or falsified empirically, it is a matter of our internal conviction. Value judgements are treated by philosophy. Sciences which only deal with analytical judgements are positive sciences. [...] [T] he natural sciences can be objective in the true sense of the word. However, in the social sciences, value judgements keep imposing themselves on the scientists at each step - after all, the social scientists are examining human relations they are integrated in, themselves. Barely any economist manages to take a distance from his own value judgements. Nevertheless, we need to keep trying. Economics, as long as it is supposed to be a real science, has to be a positive science and deal with analytical judgements only. These are the limits of the science we need to respect. You may oppose why an economist should stay away from moral discussions, why should he not deal with human rights or social justice? Sure, he can. However, at that moment, he crosses the limits of the science and enters the territory of political and moral philosophy. Values represent our emotional nature. Whoever is looking at the world through his values can perceive it, experience it, become enthusiastic about it or condemn it - but he cannot recognize it scientifically. (Holman, 2007, p. 4).

Using different terms, both authors describe the same. At the same time, both authors are partially true and partially wrong. What they both are true about is that economics is a positive science, using the term of John Neville Keynes, i. e. a science which - by its own nature deals with positive statements (Mankiw) or analytical judgements (Holman). Economics simply has nothing to say on such a phenomenon as social justice, as Holman says correctly. What both authors are wrong about is that they misidentify science with positive science only. By this, they identify the extension of science too restrictively. When Mankiw says Deciding what is good or bad policy is not just a matter of science. It also involves our views on ethics, religion, and political philosophy., he implicitly assumes validity of a following premise: Ethics, religion and political philosophy are not sciences. Analogically, when Holman says [...] at that moment, he crosses the limits of the science and enters the territory of political and moral philosophy., he implicitly assumes validity of the premise: political and moral philosophy are not sciences. 
To sum up, according to both Mankiw and Holman, economics is a science because its statements can be tested empirically while moral and political philosophy is not a science because its statements cannot be tested empirically. Reduction of the sphere of science to the empirically testable statements is based on the fallacy of empiricism which reduces the sources of our knowledge to experience alone. (More on this topic see Fuchs, 1995, pp. 101111). Why is empiricism a fallacy? When Holman says: $\boldsymbol{A}$ value judgement cannot be verified or falsified empirically, it is a matter of our internal conviction. [...] Economics, as long as it is supposed to be a real science, has to be a positive science and deal with analytical judgements only. (Holman, 2007, p. 4), he not only expels value judgments from the sphere of (real) science but he also presents a self-contradictory statement. In fact, the statement that empirically non-testable judgements are just "a matter of our internal conviction" is not empirically testable itself, ergo: it is just a matter of the author's internal conviction. However, the author does not present this statement as a mere matter of his own internal conviction. He presents it as objectively valid. This is a contradiction. Suffering from the empiricist reductionist fallacy, both authors crowd the normative statements of moral and political philosophy out of the sphere of "objective" to the sphere of "subjective". If this were true, the consequences would be tremendous. If the question of good and evil is a subjective one, then there is no objective basis of the morality. If the morality is not objectively based, then the whole question of justice is simply a question of force. What is just? Just is what the legislator says is just. The infinite regression in pursuit of a definition of "just" resulting from this approach is obvious. What our feeling that something is unjust, then? Holman answers: emotions. However, giving up on the objective morality leads to a relativization of a crime and guilt. The judges, prosecutors and cops are no better than the criminals they are after.

There is another interesting insight, too. Economics is a positive science. By its nature, economics is unable to address the problem of justice. The question of justice falls within the purview of moral and political philosophy. While applied metaphysics (such as moral and political philosophy) deals with the very (sensitively unobservable) essence of a human being, empirical sciences deal only with (sensitively observable) accidents of a human being. So, the positive/normative dichotomy is not the only thinkable typology of sciences. With respect to the epistemological aspect of human knowledge, the metaphysical/empirical dichotomy is more appropriate. While Mankiw and Holman crowd moral and political philosophy out of the sphere of science, I contend - in accordance with the viewpoint of classical philosophy - that economics, no matter how emancipated from her mother science, philosophy, it can present itself, is, was and always will be an auxiliary discipline and tool of moral and political philosophy, just as mathematics is an auxiliary discipline and tool of physics. So, if I dare to address a philosophical problem of justice on the pages of an economic journal, my selfconfidence originates in this piece of knowledge: it is not a just-wage problem we are going to discuss here but rather a wage-justice problem. From the perspective of economics, justice is as accidental feature of wage: wage may but does not need to be just. From the perspective of philosophy, though, wage is an accidental feature of justice: justice can be realized either in the sphere of wage relations or in the sphere of different relations. Now, as I said, in the hierarchy of sciences, moral and political philosophy stands higher than economics because moral and political philosophy (i. e. applied metaphysics) deals with the essence of a human being (i. e. the necessary features of a human being without which a human being would not be fully human), while economics (empirical science) deals with accidental (not necessary) features of a human being: relations he enters, quantities and non-essential qualities he acquires etc. Because moral and political philosophy stands higher than economics, the wagejustice perspective should take precedence over the just-wage perspective. With the wage- 
justice perspective in mind, it should be obvious why the topic of a just wage is perfectly appropriate to be discussed on the pages of an economic journal. 


\section{Educational Aspects}

The general trend in education of the last two centuries and especially of the last decades is: specialization. Starting at the secondary school, a student is asked and invited to focus on the object of his interest. Choosing a university and a faculty, a student picks one discipline he wants to dedicate his life to. At the university, the specialization continues: after passing the obligatory courses, a student is asked to choose from a variety of courses, depending on his supposed future profession. The higher he climbs of the educational ladder, the more he knows about a still narrower and narrower area of human knowledge. Achieving the PhD level, a student can call himself a real expert in what he is interested in. The educational specialization has a good justification: a division of labor. It sounds natural that if you do not need to waste your time and distract yourself by studying what you are not directly appealed by, you can devote this extra time to studying what you have a natural affiliation to.

There is the other side of this coin, though. An expert in his field who does not distract himself by the topics of other disciplines and who does not waste his time on studying problems of related sub-disciplines is not only an expert in his field but also an ignorant as concerns anything else but his narrow area of interest. An economist is a complete ignorant when it comes to biology, physics or philosophy. A biologist, on the other hand, is completely incompetent in questions of economics, physics or philosophy. And so on. Why should one care about it, you can object. After all, an economist does not need to orient himself in biology or philosophy. A biologist does not need to keep track of the discourse in economics or philosophy, does he? We can argue that a narrowly specialized expert becomes an easily influenceable simpleton who is sentenced to just believe what the so-called authorities in the respective disciplines tell him he is supposed to believe. Nevertheless, a real problem arrives when a narrowly specialized expert in his field starts to express himself to questions of other disciplines without even realizing that he is incompetent to do so. It is not that common that an economist would express himself to questions of biology or that a biologist would express himself to questions of economics. What is only too common, though, is that these narrowly specialized experts from various disciplines express themselves to problems of philosophy. Why could a biologist not be interested in philosophy, actually? Of course, he could. A problem is not a biologist interested in philosophy talking about philosophical problems as a self-taught philosopher. After all, it is not a degree what makes you an expert but the knowledge of the discipline. A problem is a biologist interested in philosophy talking authoritatively about philosophical problems from his position of a biologist. A problem is an economist interested in philosophy talking authoritatively about philosophical problems from his position of an economist.

Now, a biologist or an economist addressing a philosophical problem as a biologist or an economist, respectively, is a problem not because of some artificially constructed interdisciplinary barriers. Not because whoever does not have a degree is not competent to talk. It is a problem because biology or economics deal with sensitively observable (i. e. empirical) characteristics of beings or a man, respectively. Philosophy deals with sensitively unobservable (i. e. metaphysical) characteristics of beings or a man, respectively. When a biologist expounds the theory of evolution, he leaves the field of empirical phenomena and enters the field of metaphysical phenomena. The theory of evolution is metaphysically impossible, though. (More on this topic see Fuchs, 2009a, 2009b). Similarly, an economist who says that empirically non-testable statements are subjective (or just a matter of our internal conviction) not only leaves the field of empirical phenomena and enters the field of metaphysical phenomena but he also presents a self-contradictory statement. 
Such and similar mistakes originate in the educational concept based on a narrow specialization. The cure is inter-disciplinarity in education and practice. Unfortunately, the inter-disciplinarity in education is very often thought as being satisfied by enriching the list of obligatory courses by courses called "Introduction to...". So, a future economist passes the "Introduction to Law", "Introduction to Philosophy", "Introduction to History" and, most probably, this is the last time he meets the law, philosophy and history from the perspective of law, philosophy and history, respectively. From now on, he will be trained to address legal issues, philosophical issues and historical issues from the perspective of economics. This is not a real inter-disciplinarity in education, though. The real inter-disciplinarity in education tries to eliminate the arrogance of one-discipline approach and to establish a relevant-discipline approach. However, the real inter-disciplinarity in education not reached by the nominal interdisciplinarity, either. For example, studying the economic aspects of law is only playing the inter-disciplinarity. The real inter-disciplinarity in education is training the students to recognize which discipline a particular problem is taken from, i. e. to recognize the discipline-specific nature of a particular problem. For example, a student which is well-trained in interdisciplinarity, when he meets the problem of just wage, he can say: as much as this problem concerns justice, it should be treated by the analytical tools of moral philosophy; and as much as this problem concerns wages, it should be treated by the analytical instruments of economics.

The relevant-discipline approach to inter-disciplinarity in education I am suggesting requires to abandon the educational concept of narrow specialization and one-discipline optics which is dominating the university education at the present day. The relevant-discipline approach I am suggesting requires an organic, systemic reshaping of the current system of university education. It requires to kind of re-evaluate the emancipation process in the development of scientific disciplines over the last two centuries. This paper has an ambition to set an example of this proposed relevant-discipline approach to inter-disciplinarity in education.

\section{A Just Wage and A Typology of Justice}

What is just? Just is to give everyone his due. He meets the requirements of justice who keeps giving everybody what they deserve. However, according to the classical AristotelianThomistic typology (see e. g. Summa Theologica II-II, q. 61; Commentary on the Nicomachean Ethics, Book V, 888f., 927f.), there are three kinds of justice. The basic distinction is being drawn between the legal justice and particular justice, where the latter can be broken down into distributive justice and commutative justice. Legal justice (iustitia legalis) or social justice is a norm of behavior of an individual towards a community, while particular justice (iustitia particularis) is a norm of behavior towards an individual. Commutative justice (iustitia commutativa) or justice in exchange is a norm of behavior of an individual towards another individual. Distributive justice (iustitia distributiva) is a norm of behavior of a community towards an individual. Commutative justice is done if the exchange is equal, i. e. if what I give to you has the same exchange value as what you give to me. (See e. g. Gordley, 1981; Maslo, 2017). Distributive justice is done when the common resources of a community are being distributed among individual members of the community in such a way that the ratios of a transfer to an individual member over the member's contribution to the community's welfare are equal for all members of the community. (See e. g. Keyt, 1991).

Is a payment of a just wage an act of a legal, commutative or distributive justice? Kennedy (2010) distinguishes what he calls ordinary employment from non-ordinary employment. He 
defines ordinary employee as a properly qualified employee working full-time [...] in a nonentry level position and expecting to support himself/herself and his/her family from his/her earnings. (Kennedy, 2010, p. 10). A non-ordinary employee is then an employee about which it holds true at least one of the following: 1) the employee is not yet properly qualified for the job, 2) the job is temporary, 3) the job is part-time, or 4) the job is entry-level. (Kennedy, 2010, p. 10). Now, a payment of a just compensation (i. e. wage plus non-monetary benefits) in case of an ordinary employee, according to Kennedy, is an act of distributive justice, while a payment of a just compensation in case of a non-ordinary employee is an act of a commutative justice. Kennedy explains it like this: The employment relationship is not normally the exchange of labor for a wage; it is commonly participation in a community of work. For ordinary employees who do participate fully in a community of work, fairness in compensation is determined by the principles of distributive justice, with special emphasis given to the protection of the human dignity of the employee. For other, non-ordinary employees, who do not participate fully (or perhaps at all) in a community of work, fairness in compensation is determined by the principles of commutative justice. (Kennedy, 2010, p. 16).

In other words, the employer and his employees represent a "community of work", the total product of a joint employment of the capital, labor and entrepreneurial skills represent the total resources in possession of the community and the task we face is a just distribution of the total product among capital, labor and the entrepreneur. Let us assume the capital away, for sake of simplicity (or let us assume that the capital is in possession of the entrepreneur). The total product needs to be distributed between individual employees and the entrepreneur. The remuneration of the entrepreneur is called a profit. However, the topic of a just or fair profit represents a separate problem which will be treated at another occasion. At this moment, the problem is how much each employee should be paid. According to the principle of distributive justice, says Kennedy, the individual employees should be paid in such a way that first of all [...] basic needs be met (and so there will be a minimum fair level of compensation) and secondly that similar employees be treated similarly. (Kennedy, 2010, p. 15). Obviously, Kennedy is adding an additional criterion of distributive justice. In addition to the abovementioned feature of distributive justice (ratios of a transfer to an individual member over the member's contribution to the community's welfare are equal for all members of the community $)^{3}$, the requirement that each ordinary employee is being provided at least a minimum fair level of compensation ${ }^{4}$.

The problem I can see in Kennedy's treatment of the just compensation (just wage) to an ordinary employee as an act of the distributive justice is the concept of a "community of work" and especially its corollary: common resources in the possession of the community. The total product of the joint employment of labor and entrepreneurial skills is not in possession of a "community of work" consisting of the employees and the entrepreneur. The total product of the joint employment of labor and entrepreneurial skills is in possession of the entrepreneur. How do I know? Let us assume that - as a consequence of a decrease in the market demand - the market value of the total physical product decreases to zero. If the total physical product were in a common possession of the "community of work", then the employees would only have a claim to their respective portion of this physical product (the market value of which is zero now). However, this is not the case as we know because despite the fact that the market

\footnotetext{
${ }^{3}$ Which Kennedy calls "the principle of contribution"

${ }^{4}$ Which Kennedy calls "the principle of dignity": Consequently, no one has a just claim on an income more than sufficient to meet the requirements of decent human life until every member of the community has received a minimum income. (Kennedy, 2010, p. 12).
} 
value of the physical product is zero, each employee has a right to be paid his monetary wage which is not zero. If the employees had a right to a share of the profits, the justice commands that they should take part in bearing the losses, too. In that case the employees would be partners, not employees. (Compare Miklík, 1947, p. 79; Vodička, 1946, Part IV, Ch. VIII, pp. 36-37, 38-39). This is why I don't think the claim of an ordinary employee to a just wage is based on the principle of the distributive justice. ${ }^{5}$

According to Burke (2010, p. 301), a payment of a just wage is neither an act of commutative, nor distributive justice but a legal or social justice. While commutative justice is a norm of conduct of an individual in relation to another individual, distributive justice is a norm of conduct of a community in relation to an individual. Legal or social justice is a norm of conduct of an individual in relation to a community. A community member is acting in compliance with legal or social justice as long as he is giving the community its due. A community's goal is a common good. Therefore, who contributes to the common good is giving the community its due. A payment of a just wage is supposed to make sure that a wife of an employed man does not have to spend time in work and leave the children's upbringing to other people. This mischief is ruining a family. (Compare Storck, 2019). Since a functioning family represents the foundations of the state, a functioning family is a common good, i. e. what a state is supposed to strive for. If an employer pays a just wage, he contributes to the state's care for a functioning family and, as a result, contributes to the common good. (Compare Miklík, 1947, pp. 81-82, 85). A payment of the just wage is thus an act of legal or social justice. So much to Burke's exposition.

We can ask another question, though. If a payment of a just wage is an act of legal or social justice, i. e. a norm of conduct of an individual in relation to a community, then, if an employer does not pay his employee a just wage, the employer commits an act of injustice in relation to the community, not the employee. However, it is not only the community which is suffering by the payment of an unjust wage but the employee, as well. So, it cannot be denied that, under conditions, an employer commits an act of injustice in relation to his employee, too. Injustice committed by an individual in relation to an individual is commutative injustice, i. e. violation of the principle of the equality in exchange. An employee does not receive a wage equivalent to the value of his labor. A value of an employee's labor is equal to the marginal revenue of his product of labor, though, which can be lower than a sum needed to support his family. Therefore, it seems that commutative justice is done if an employee gets a wage equal to the value of his marginal product.

Now, in the perfectly competitive labor market, the value of the marginal product of labor is decreasing as the quantity of labor employed increases. The result is that the value of the marginal product of labor of the last laborer employed determines the wage of all remaining employed laborers. Does this mean that the commutative justice is done only in the case of

\footnotetext{
${ }^{5}$ Another question is whether it is a violation of distributive justice if the entrepreneur pays the same wage to two employees even though one of them works harder than the other. In this connection, Demirel, Yücel (2013, pp. 2728) talk about organizational justice. My opinion is that it is not a violation of distributive justice because it is not the resources in possession of the community which are being distributed among the members of the community according to the merits of the respective members of the community but the revenues of the entrepreneur from which the entrepreneur has an obligation to pay his employees just wages. A member of the community has a claim to his just share of the resources in possession of the community because he is a member of the community. In this sense, the resources distributed to a member of the community never stop being in the possession of the community because the member of community owns them not as an individual but exactly as a member of the community. An employee does not own his wage as a member of the firm but as an individual. The wages distributed to the employees stop being in the possession of the firm.
} 
the last laborer employed while the remaining laborers are paid an unjust wage? At the first sight, it would seem so. The reason why this is not the case needs to be looked for in the homogeneous nature of the employed labor force. If you employ laborer A, first, and then laborer B, the value of A's marginal product of labor will be higher than value of B's marginal product of labor. However, if you employ laborer B, first, and then laborer A, the value of B's marginal product of labor will be higher than value of A's marginal product of labor. Would it be just to wage-discriminate the laborers, i. e. to pay each laborer a wage equal to the value of his marginal product of labor? In that case, though, the employer-entrepreneur would have no profit. The whole product would be distributed as wages to the laborers. This would be an obvious injustice in relation to the entrepreneur. The thing is, what we call "value of the product of labor" represents the total product, not only the portion of the product to which the labor force has contributed. The economic language is confusing us at this point. Analogically, what we call "value of the marginal product of labor" represents the increment to the total product, not only the labor's contribution to the increment to the total product. So, the commutative justice cannot be done by paying laborer a wage equal to the value of "his" marginal product of labor. The perfectly competitive labor market draws the division line at the level equal to the value of the marginal product of labor of the last laborer which is still employed. The commutative justice is done when equal value is being exchanged for the equal value. As long as the labor force is homogeneous, it is impossible to say whether laborer A's value of marginal product is higher than that of laborer B's or vice versa. Paying an equal wage to A and B seems just, then. What is the level of this wage, though? Since the labor force is used jointly with the entrepreneurial skills of the employer-entrepreneur, the problem does not seem to be possible to solve by a reference to the principle of the equality in exchange.

The problem seems to be a problem of a just distribution of the total product to which both the labor and the entrepreneur contributed. However, there is the objection against Kennedy (2010) presented above: if the business faces a decrease in demand which lowers the value of the total product to zero (in the extreme case), the entrepreneur still has to pay the wages to his employees. In the opposite case, the employees would share the entrepreneurial risk with him which means they would be his partners. So, it's not the market value of the labor's contribution to the total product which could be used to calculate the just wage. It's the reward of the labor as such, regardless of the market value of the product of labor which is so volatile. After all, it's the laborer who is worthy of his reward, not the market value of the laborer's marginal product. So, it is the commutative justice which entitles a laborer to his just wage, in the end. ${ }^{6}$ However, it's not the market value of the product of labor which constitutes the equivalent of the wage but the value of the laborer's performance which contributes to the production of the total physical product. ${ }^{7}$ And the value of this performance is given by the expenditures which ensure that the laborer's life is authentically human. ${ }^{8}$ Why so? Because the labor performance has its natural purpose (causa finalis) which is making a living.

\footnotetext{
${ }^{6}$ Merit and reward refer to the same, for a reward means something given anyone in return for work or toil, as a price for it. Hence, as it is an act of justice to give a just price for anything received from another, so also is it an act of justice to make a return for work or toil. (Summa Theologiae, I-II, q. 114, a. 1, co.). Because payment of a just price is an act of commutative justice, this analogy implies St. Thomas Aquinas regards a payment of a just wage also an act of commutative justice. Vodička (1946, Part IV, Ch. VIII, p. 37) talks explicitly of commutative justice in this context.

${ }^{7}$ So, the wage is commensurate to the merit, i. e. to the quality and quantity of the supplied labor, not to the value of the result (Vodička,1946, Part IV, Ch. VIII, p. 37).

${ }^{8}$ We should also keep in mind that [the just wage or just compensation] must include not only the cost of the absolute essentials of life (e. g. food, clothing, shelter, medical care, education, etc.) but also the cost of those things that make life decently human. In this category we could include provisions for leisure and entertainment, religious practice, aesthetic experience, participation in cultural events, access to communication technologies, and so on. (Kennedy, 2010, p. 12). Similarly Vašek (1931, p. 306); Vodička (1946, Part IV, Ch. VIII, p. 39)
} 
(Compare Miklík, 1947, p. 80, 86). And this living must be more than a mere subsistence, it must be an authentically human living. This is why the value of the labor performance cannot be estimated lower than the cost of living. It can be estimated higher, depending on the intensity and quality of labor (Miklík, 1947, p. 80), but never can it be estimated lower than the cost of authentically human living.

To have the legal or social justice done, a paid wage needs to cover the employee's expenditures needed to support his family. ${ }^{9}$ So, by saying that an employee has a right to a just wage, we mean something different than by saying that an employer has an obligation to pay his employee a just wage. An employee has a right to his (value-of-performance) wage on the grounds of commutative justice. An employer has an obligation in relation to his employee to pay a just (value-of-performance) wage on the grounds of commutative justice. On top of that, an employer has an obligation in relation to the community to pay a just (family) wage to his employee, on the grounds of legal or social justice. What about an argument of the employer, then, that supporting his employee's family is none of his business? Well, it is his business. Equally as a parent, by the act of a conception, takes upon himself obligations which arise to him in relation to the conceived baby, an employer, by an act of employment, takes upon himself his employee's obligations resulting from the latter's nature, proportionately to his workload. Not only that, if the reason of the low wage is a low productivity of labor, the employer has an obligation to take care that the productivity of labor increases. (Abela, 2009, pp. 12-13; compare Naughton, 2000).

So, the employer has a double obligation: in relation to his employee and in relation to his community. However, the employer has no obligation to pay his employees a legally or socially just wage if, after subtraction of these wage costs, he is not left with an income sufficiently high to guarantee a life standard compatible with his station. (Worland, 2001, pp. 15-16; Vřeštál, 1916, Volume 2, Part 2, book XII, 281; Vašek, 1931, p. 305; Miklík, 1947, p. 91; compare Naugton, 2000). In that case, if he pays his employee a wage falling short of the wage needed to support the employee's family, the employer does not commit a legal or social injustice, neither formally, nor materially. ${ }^{10}$ (Compare Quadragesimo anno, 72.; Abela, 2009, p. 12).

\section{A Just Wage and A Minimum Wage}

Whether a payment of a just wage by an employer can be achieved through the legal minimum wage was, is and probably will be an object of emotional political debates. (See Worland, 2001). A just wage is one thing and making the employers pay it is another thing. Let us

\footnotetext{
9 We can agree with Pandey, Joseph (2014, p. 3), then, that justice is a matter of merit and need.

10 Now, this is something that Woods (2007) does not take into account. Woods (2007, pp. 161-162) presents a following example: Imagine a case in which the authorities have somehow managed to pinpoint the 'just wage' as $£ 5$ per hour - and assume that the requirement is not statutory but is regarded as a moral obligation by some Christian employers. Then consider employee John, and firms A and B. Firm A, not considering John's labour worth the decreed wage, passes him over for employment. Firm B, however, willing to incur the criticisms of the wage authorities, employs John at the mutually agreed-upon wage of $£ 4$ per hour. [...] Is it morally preferable for someone not to be hired at all rather than to be hired at a wage that is somewhat below whatever has been decreed as the 'just wage'? Woods does not take into consideration that if the firm B cannot afford to pay £5 per hour without its owner's standard of living compatible with his station being at stake, then it is not unjust (either formally or materially) if the firm B pays $£ 4$ per hour. As concerns the moral message of Woods' example, how does Woods know that John can either be employed for $£ 4$ per hour or not be employed at all? Saying this implies that there is no single firm in the economy where the value of John's marginal product would be higher than or equal to $£ 5$ per hour. But, even if this were the case, it would only mean the there is no single firm in the economy which could make use of an additional justly-rewarded worker. In that case, employing such an additional worker is an act of mercy in which case the employer is not morally obliged to pay a full just wage (Vřeštál, 1916, Volume 2, Part 2, book XII, 283; Vašek, 1931, pp. 305-306; Miklík, 1947, p. 91).
} 
assume that a producer determines a price of its own production as a sum of average cost and a mark-up. Volume of labor employed depends negatively on the wage rate. The higher the wage, the lower volume of labor employed (ceteris paribus). How will a producer react to increased wage costs? If the producer wants to preserve the profit level, the increased wage costs must be compensated somehow. If he is located in the elastic section of his demand curve, then, projecting higher wage cost into the price through the constant mark-up will only decrease the total revenue. At the same time, though, total wages paid can decrease because lower output implies lower labor needed. In any case, the profit cannot increase by this operation: if it could, the producer would have initiated the change already. At best, the profit will stay unchanged. If the producer wants to preserve the employment level with the increased wages, he needs to redeem the higher wages with lower mark-up. Where is the lower limit of the mark-up value? Obviously, the lower limit of the mark-up is such a value of the mark-up which guarantees a just profit to the producer. If the producer responds to the wage increase by decreasing the mark-up, so that the price does not change, then the output will not change, either, and the revenues will not change, either. The costs will increase, though, that is why the profit level will decrease. Therefore, the producer does not have any incentive to respond to the increase of the wage costs by decreasing the mark-up because the profit can only decrease, as a result.

To sum up, a producer does not choose decreasing the mark-up on his own but he needs to be motivated to do so. If the producer is supposed to not respond to the increase of the wage costs by decreasing the employment, then a decrease of the mark-up needs to be a better option for him than a decrease of the employment. This could be achieved by paying the public servants a just wage. As a result, there will occur an outflow of employees from the private sector to the public sector. A decrease of the supply of labor in the private sector will lead to an increase of the wage up to the just level. Producers having long-run contracts with their customers cannot afford such a massive outflow of labor force. Therefore, in an effort to keep their employees, the producers will increase the wages up to the just level and, at the same time, decrease their mark-ups. Will the optimal level of output not decrease in the long run? Will the optimal level of employment not decrease and will the mark-up not go back to the initial level? In that case, a decrease in the supply of output in all markets would occur which would lead to a stagflation. Nevertheless, the public servants with their just wages will pull the aggregate demand up which will shift the demand curves for the output of all producers which will increase the optimal level of output and employment. The problem is that the price level increase will push down the purchasing power of the just wages, at the same time, which will neutralize the initial wage increase. So, if the producers, instead of decreasing their mark-ups, will project the increase of the wage costs into the higher prices, the following inflation will partially or fully neutralize this increase of wages to the just level.

Another way to make the producers increase the wages to the just level without subsequent massive layoffs and without a subsequent inflation is to make the producers decrease their mark-ups: through tax measures pointed against layoffs. However, this leads to inflexibility of labor markets, in the end, whereby the producers - practically unable to fire anyone - will not hire almost anyone, waiting for the employment level to keep decreasing very slowly to the desired optimum. The result is then a permanently increasing unemployment rate. Whoever loses a job, he can be sure he will not find a new one. So, it seems that the tendency of the producers to profit maximization cannot be broken by force. The only way to make producers decrease their mark-ups and increase the wages to the just level is to create such an institutional environment in which the managers and owners will want to pay the just wages 
themselves. ${ }^{11}$ This conclusion is in accordance with the conclusions of Worland (2001, pp. 1617) and is complementary to the conclusion of Abela (2009) who proves that the legal minimum wage violates the subsidiarity principle. ${ }^{12}$ The proponents of distributism are stressing the necessity of employees to acquire property which will be source of their economic freedom. (See e. g. Belloc, 1936). The reason is obvious: a laborer who has incomegenerating property of his own is not vitally depending on the wage from his employer; such a laborer will not accept an unjust wage that easily; with a sufficient amount of laborers commanding income-generating property, the market supply of labor decreases; this will force the employers to increase the wage up to the just level; once the wage reaches the just level, the wage rigidities will make sure it will not decrease even if the labor supply increases later. The way to "restoration of property" may be tax reliefs to employees and free lances.

\section{A Just Wage in A Historical Perspective}

Laissez-faire proponents are usually arguing that the industrial revolution led to an increase in the standard of living (e. g. Cameron, 1993, p. 190; Mises, 1949, p. 615 ${ }^{13}$ ) The population was migrating massively from the countryside to the emerging cities where it was working for a wage as a proletariat. (Cameron, 1993, p. 189). This wage, so the laissez-faire advocates, was substantially higher than the income achievable in the countryside, otherwise people would not have moved to the emerging cities. ${ }^{14}$ Sounds logically. Why, then, towards the end of the $19^{\text {th }}$ century when the real wages were substantially higher than during the industrial revolution, Leo XIII criticizes the unjustly low wages? I mean, why did the popes not criticize low wages in the centuries before the industrial revolution? Next, a just wage (in the sense of legal or social justice) is such which enables an employee to support himself and his family (adequately to their station) and to generate some saving. It is such a wage which makes sure that a wife can take care of the children and devote her time to upbringing thereof. Which is connected to Leo XIII's criticism of employment of women and children. Yet, the laissez-faire apologists will object here that women and children were working in the centuries before the industrial revolution, only that they were not working for a wage..$^{15}$

First of all, the unjust wage phenomenon - in the sense of legal or social injustice - can only arise in the wage relation. A feudal peasant who had some land rented on which he and his family were farming and who made his living from the returns of this land could not be paid an unjust wage. The peasant was not a contractual party in a wage relation. Whatever the level of his income, then, it could not be an unjust wage. Next, a just wage in the sense of legal or

\footnotetext{
11 Which is something that Woods does not seem to understand: In a certain sense, though, whether or not the social encyclicals call for a legally mandated minimum wage or whether they simply declare

the employer to be morally bound to provide one is largely immaterial. To a Catholic employer who believes the Catholic Church is of divine institution, there may be little practical difference between a minimum wage that is imposed legally and one that is imposed on his conscience by the official teaching of a national bishops' conference. (Woods, 2007, p. 152).

12 Abela (2009, p. 15) is arguing along the same line: the important and complex issue of justice in wages cannot be solved by any single, one-size-fits-all solution.

${ }^{13}$ Mises describes this hypothesis more than vividly: It is a distortion of facts to say that the factories carried off the housewives from the nurseries and the kitchens and the children from their play. These women had nothing to cook with and to feed their children. These children were destitute and starving. Their only refuge was the factory. It saved them, in the strict sense of the term, from death by starvation.

${ }_{14}$ Mises (1949, p. 615) is arguing along this line: The factory owners did not have the power to compel anybody to take a factory job. They could only hire people who were ready to work for the wages offered to them. Low as these wage rates were, they were nonetheless much more than these paupers could earn in any other field open to them. ${ }^{15}$ Cameron (1993, p. 189) argues at this point: Many accounts of the so-called industrial revolution in Britain stress the employment of women and children in the factories, as though it were a novelty; nothing could be further from the truth. The employment of women and children in both agriculture and domestic industry was a phenomenon of long-standing, which the factory system merely adopted.
} 
social justice is a family wage (able to generate saving). However, if we said that women and children had to work centuries before the industrial revolution, even though not for a wage, it would follow that the real income of the peasants before the industrial revolution did not reach the level of the just wage. Now, this is not necessarily the case. The reason why - according to Leo XIII and Pius XI - a wage of an employee should be high enough to support him and his family is that the woman and the children do not have to enter a wage relation, not that they do not have to work. (See Burke, 2010, p. 301; Quadragesimo anno, $71 .{ }^{16}$ ). There is difference, here. Women were working before the industrial revolution, of course. However, they were working at home and on the family property. ${ }^{17}$ Small children and girls were helping their mother with this housework, boys from a certain age up were helping their father on the field. They were still with their parents, though. Through the fact that the whole family was working on its property and the children together with their parents, the family life and the working life were merging into one. From the industrial revolution on, the family life and working life get separated. ${ }^{18}$ The reason is partly that labor began to get hired for a wage and therefore it became a complement to someone else's capital - and partly because man, woman and children usually were employed in different jobs when hired for a wage and therefore they did not spend their working time together.

If the laissez-faire proponents insist that the real income of a feudal peasant was lower than the real wage of a worker from the industrial revolution onwards, they do not take into account one important "consumption commodity": family life. Real income of a feudal peasant allowed his family, in the given institutional environment, that the children grew up with their parents and that the woman could fulfill her role of a wife and mother. On the other hand, real wage of a worker from the industrial revolution onwards did not allow his family, in the given institutional environment, to be functioning as a family. If we include the commodity family life in the consumption basket, the proposition of laissez-faire ideologues about the increase of real income thanks to the industrial revolution does not seem so self-evident. It can even be argued to the contrary. A following objection can be expressed, at this point: why did people go to work in the factories if it was ruining their families and was making them worse-off, in the end? We can answer by a question: why do some individuals pledge the family property and ruin the family life just to be able to keep on gambling or drinking if it makes them worse-off, in the end? The industrial factory workers either had no choice because, with respect to the population growth, the countryside economy was unable to absorb them (Cameron, 1993, p. 189), or their consumer preferences changed simply: a commodity family life began to be preferred relatively less as compared to other goods. In the first case, the above said objection is pointless because people were going to work in the factories for an unjust wage just avoid a greater evil, i. e. stay in the countryside unemployed.

If we admit the second possibility, i. e. people were leaving the countryside voluntarily, a laissez-faire advocate would probably argue that, since utility is subjective, the industrial workers were better-off, at the end of the day, because the family life had a lower weight in their utility function than other goods which they could buy now. A strong argument, indeed.

\footnotetext{
${ }^{16}$ It is an intolerable abuse, and to be abolished at all cost, for mothers on account of the father's low wage to be forced to engage in gainful occupations outside the home to the neglect of their proper cares and duties, especially the training of children.

17 Or a nobility's property which the family was using on the grounds of a long-term, hereditary rental contract.

18 Yuengert (1996, p. 102) talks in the same spirit, noticing that: Premodern (or pre-market) society was unitary most men lived in small, tightly knit social circles which shaped their character, and provided them with work and meaning. [...] In modern societies, the principles of division of labor and comparative advantage have produced a society in which every person belongs to several overlapping social circles. Few people work, worship, learn and live in the same places anymore.
} 
However, this argument neglects the fact that a man has an obligation to preserve his life and support his family. If a man quits a job in which he could fulfill these obligations to take a new job in which he cannot fulfill these obligations, he can be better-off subjectively but he has no right to do so. A man who voluntarily accepts a job for an unjust wage and, as a result, forces his wife to start working for a wage and leave the upbringing of their children to other people, he is ruining his family and, as a result, endangers the common good. Therefore, he commits legal or social injustice, both material and formal, in relation to the community. ${ }^{19}$ At the general level, the above said objection draws upon an erroneous premise that everybody is choosing his life's goal. The opposite is truth. The life's goal is objectively given. ${ }^{20} \mathrm{~A}$ human being that is missing this objectively given goal is objectively worse off as compared to someone who achieves this goal. Therefore, a change of consumer preferences away from the commodity family life implies legal or social injustice. Since nobody has a right to commit injustice, a man has no right to voluntarily work for an unjust wage and to send his wife to work for a wage and to leave the upbringing of their children to other people. To strive for an increase in the standard of living is only a legitimate goal as much as the achievement of this goal does not prevent a human being from meeting his objective obligations.

The wage relation, especially in the factory, did not allow the children to work together with their parents. The wage relation led to the alienation of labor, i. e. the labor served as a complement to someone else's capital, not the worker's own capital. In other words, the worker - unlike the feudal peasant - did not work on his own property. As a result, the realization of the wage relation in the period from the industrial revolution onwards is accompanied with the separation of the family life and working life. This separation of the family life and working life results in the weakening of the natural distribution of roles in the family. Man is no more primarily the breadwinner father. Woman is no more primarily the wife and mother. Children are no more brought up primarily by their parents. The traditional model of a family is dealt the first heavy blow in the families of the poorest ones. The roots of the female emancipation are to be looked for here. If each family member enters his own wage relation, it strengthens the spirit of independence from the rest of the family. This is naturally weakening the traditional patriarchal model.

Despite the fact that the crushing majority of population of the Christian Medieval and Modern Europe made its living by farming and did not enter the wage relation, in effect, a small fraction of population was living in towns and cities and was a contractual party in a wage relation, either as an employer or as an employee. However, in the centuries before the industrial revolution, popes did not criticize the phenomenon of unjustly low wages. Does this indicate that the wages of journeymen in the workshops were high enough to enable the journeymen to support their families? Next, what gives the worker a right to such a wage if the employerentrepreneur is not sure whether - after the payment of wages to his employees - he will be left enough to buy a loaf of bread? The thing is, the employer-entrepreneur, unlike his worker, bears the entrepreneurial risk. The demand for his production undergoes fluctuations and the employer-entrepreneur never knows whether he ends up with a profit or a loss. Let us begin with the second objection. First of all, that an entrepreneur ends up with a loss does not mean that he cannot afford to buy a loaf of bread. That he suffers a loss does not mean that he does not have cash. Profit/loss statement and cash-flow are two different things. Next, an

\footnotetext{
${ }^{19}$ If he is doing so involuntarily, he does not commit legal or social injustice, either formally or materially. He would commit material legal or social injustice if he were doing it voluntarily but suffering a non-culpable ignorance about the fact that it is an act of legal or social injustice.

20 The proof is supplied by philosophical anthropology and philosophical ethics. This proof is ontologically anchored. Its exposition would go beyond the scope of this paper, though, and I can present it at another opportunity.
} 
entrepreneur which goes bankrupt can still go working for a wage. As concerns the level of wages paid to the journeymen, Leo XIII himself suggests that the guild system was ensuring payment of just wages: History attests what excellent results were brought about by the artificers' guilds of olden times. They were the means of affording not only many advantages to the workmen, but in no small degree of promoting the advancement of art, as numerous monuments remain to bear witness. (Rerum Novarum, 49.) According to Richardson (2005, pp. 154-155), who refers to the common meaning of contemporary commentators and modern historians and who in other respects gives a positive account of the guild system, the masters were colluding to lower the wages paid to the journeymen. If we admit that the guild system of the Medieval and Modern Europe did not ensure payment of just wages, there is probably no other explanation but that the popes did not criticize this mischief simply because it afflicted a relatively very small fraction of population and so did not represent - unlike the industrial era a mass phenomenon. Besides, each journeyman was to become a master, sooner or later, unlike an industrial worker who would probably never become an entrepreneur.

\section{Conclusion}

As a cure for mistakes originating in inter-disciplinary transgressions, I suggest interdisciplinarity in education which would eliminate the arrogance of one-discipline approach and establish a relevant-discipline approach. The real inter-disciplinarity in education, I contend, is training the students to recognize which discipline a particular problem is taken from, i. e. to recognize the discipline-specific nature of a particular problem. The relevant-discipline approach to inter-disciplinarity in education I am suggesting requires to abandon the educational concept of narrow specialization and one-discipline optics which is dominating the university education at the present day. This paper has an ambition to set an example of this proposed relevant-discipline approach to inter-disciplinarity in education.

A man has an obligation to preserve his life and to support his family. A man meets this obligation if he works. If he still does not earn enough to support himself and his family, he does not sin, according to the Catholic social teaching, as long as his low income is determined by circumstances out of his control. If a man works for a wage, his employer has an obligation to pay him a family wage. If the employer does not pay such a wage to his employee, even though he could (without depriving himself of the standard of life corresponding to his station), then he commits legal or social injustice which is either material or formal (depending on a degree to which his action is conscious or to which his potential ignorance is culpable). I draw upon the finding that a payment of a just wage is an act of legal or social justice and I argue that the term "just wage" can be perceived in two meanings: 1) in the meaning of legal or social justice, a just wage means - in compliance with Rerum Novarum and Quadragesimo Anno - a sum needed by an employee to support himself and his family; 2) in the meaning of commutative justice, a just wage is equal to the value of the employee's performance which contributes to the production of the total physical product. Where the value of the labor performance cannot, in compliance with the principle of commutative justice, be estimated lower than the cost of living. It can be estimated higher, depending on the intensity and quality of labor, but never can it be estimated lower than the cost of authentically human living. In this point, my research is in agreement with the results of Burke (2010) in the matter of social justice and Vodička (1946) in the matter of commutative justice and opposes the conclusions of Kennedy (2010) in the matter of distributive justice. In this paper, I contend, in accordance with Worland (2001) and Abela (2009), that the legal minimum wage is not an effective way to make the employer pay a just wage. I claim that the only way to make the employer pay a just wage is a creation of such an institutional environment in which the owners and managers will 
want to pay just wages on their own, at the expense of their own mark-up and their own profit. I state that a distributist vision of "restoration of property" proposed by Belloc (1936) could provide a functional solution to this.

According to laissez-faire proponents (Mises, 1949; Cameron, 1993), real incomes of peasants prior to and during the industrial revolution were lower than real wages of industrial workers during and after the industrial revolution. However, popes prior to Leo XIII - whose pontificate dates back in the period after the industrial revolution - did not criticize either the unjustly low incomes of peasants or the unjustly low wages of journeymen in the workshops. The reason why the popes prior to and during the industrial revolution did not criticize low incomes of peasants is twofold, to my opinion. First, peasants were using land on the grounds of a long-term rental contract from the nobility which means they did not enter a wage relation. Since they were not being paid a wage but they were living on the revenues from the land, the peasants could not be being paid an unjust wage, as a matter of logic. Second, I challenge the statement that the real income of a feudal peasant did not reach the level of the just (family) wage. The legal or social injustice in a wage relation occurs when a man's wage does not allow his wife to be a full-time mother. However, even though a woman and children had to work in the centuries prior to the industrial revolution (albeit not for a wage), this did not prevent the woman to be a full-time mother. The reason was that the working life and family life in the feudal countryside were not separated (Yuengert, 1996). So, if we include the commodity "family life" into the consumption basket, then a postulate of laissez-faire advocates concerning the increase of real income thanks to the industrial revolution can be questioned and even the opposite can be contended. The reason why the popes prior to and during the industrial revolution did not criticize low wages of journeymen in the workshops is not, to my opinion, that the guild system ensured payment of just wages but that the fraction of journeymen in the population was relatively very small, compared to the later fraction of industrial workers in the population. So, it was a partial injustice which the popes did probably not feel the need to react to by the magisterium. Besides, each journeyman was to become a master, sooner or later, unlike an industrial worker who would probably never become an entrepreneur.

\section{References}

Abela, A. (2009). Subsidiarity and Just Wage: Implications of Catholic Social Teaching for the MinimumWage Debate. Journal of Markets \& Morality, Spring 2009, Volume 12, Number 1, 7-17.

Belloc, H. (1936). An Essay on the Restoration of Property. IHS Press, 2002. ISBN-13 (eBook): 978-1932528-23-7

Burke, J. (2010). Distributive Justice and Subsidiarity: The Firm and the State in the Social Order. Journal of Markets \& Morality, Fall 2010, Volume 13, Number 2, 297-317.

Cameron, R. (1993). Concise Economic History of the World (2 ${ }^{\text {nd }}$ Edition). Oxford University Press, 1993. ISBN 0-19-507446-7

Demirel, Y., Yücel, İ. (2013). The Effect of Organizational Justice on Organizational Commitment: A Study on Automotive Industry. International Journal of Social Sciences. [online]. 2013, Vol. II, No. 3, pp. 26-37. ISSN 1804-980X. Retrieved from: https://www.iises.net/download/Soubory/soubory-puvodni/pp026-037 ijoss 2013V2N3.pdf 
Fuchs, J. (1995). Filosofie. 2. Kritický problém pravdy. Krystal OP, 1995. ISBN 80-85929-06-6.

Fuchs, J. (2009a). Filosofická diskuse o evoluční teorii. Distance, 2009, č. 1. ISSN 1212-7833. Available at: http://www.distance.cz/rocnik-2009/1-cislo/filosoficka-diskuse-o-evolucni-teorii

Fuchs, J. (2009b). Vysvětlení argumentace proti evoluční teorii. Distance, 2009, č. 2. ISSN 1212-7833. Available at: http://www.distance.cz/rocnik-2009/2-cislo/vysvetleni-argumentace-proti-evolucniteorii

Gordley, J. (1981). Equality in Exchange. California Law Review, Vol. 69, No. 6 (Dec., 1981), 15871656. https://doi.org/10.2307/3480255

Gordley, J. (1998). Good Faith and Profit Maximization. Review of Business, Summer 1998, Vol. 19, No. 4., 11-17.

Holman, R. (2007). Mikroekonomie. Středně pokročilý kurz. C. H. Beck, 2007 (2nd edition). ISBN 97880-7179-862-0.

Kennedy, R. G. (2010). The Practice of Just Compensation. Journal of Religion and Business Ethics, Vol. 1, Article 1. 1-17.

Keynes, J. N. (1890). The Scope and Method of Political Economy. Batoche Books, 1999. Retrieved from: https://socialsciences.mcmaster.ca/econ/ugcm/3\|3/keynesin/Scope.pdf

Keyt, D. (1991). Aristotle's Theory of Distributive Justice. In: Keyt, D.; Miller, F. D. Jr. (eds.). (1991). A Companion to Aristotle's Politics. Oxford: Blackwell, 1991. ISBN 155786098X. 238-278.

Leo XIII. (1891). Rerum Novarum. Retrieved from: http://www.vatican.va/content/leoxiii/en/encyclicals/documents/hf I-xiii enc 15051891 rerum-novarum.html

Mankiw, N. G. (2015). Principles of Economics. Cengage Learning, 2015 (7 $7^{\text {th }}$ edition). ISBN-13: 978-1285-16587-5.

Maslo, L. (2017). A Just Price: Objections and Suggested Solutions. Proceedings of 7th Economics \& Finance Conference, Tel Aviv. March 8, 2017. ISBN 978-80-87927-32-8. 215-233. https://doi.org/10.20472/EFC.2017.007.013

Miklík, K. (1947). Sociální nauka Církve III. Krystal, 1947. Available at: http://librinostri.catholica.cz/download/VodickaPrincipyMiklikPraconi-150dpi.pdf

Mises, L. von. (1949). Human Action. A Treatise on Economics. Ludwig von Mises Institute, 1998. ISBN 0-94546624-2.

Naughton, M. J. (2000). Distributors of Justice: A Case for a Just Wage. America, May 27, 2000. Vol. 182, No. 19. Available at:

https://www.americamagazine.org/issue/300/article/distributors-justice-case-just-wage 
Pandey, V., Joseph, G. K. (2014). Changing Perceptions of Fairness: Group Identity, Locus of Merit and Need, and the Preference for Norms of Allocation. International Journal of Social Sciences [online]. 2014, III(1), pp. 2-18. ISSN 1804-980X. Retrieved from:

https://www.iises.net/download/Soubory/soubory-puvodni/pp002-018 ijoss 2014v3n1.pdf

Pius XI. (1931). Quadragesimo Anno. Retrieved from: http://www.vatican.va/content/piusxi/en/encyclicals/documents/hf p-xi enc 19310515 quadragesimo-anno.html

Richardson, G. (2005). Christianity and Craft Guilds in Late Medieval England: A Rational Choice Analysis. Rationality and Society, Vol. 17(2), 139-189. https://doi.org/10.1177/1043463105051631

Storck, T. (2019). The Just Wage. The Distributist Review [online]. October 23, 2019. Retrieved from: https://distributistreview.com/archive/the-just-wage

The Holy Bible. Douay-Rheims Version, 1899. American Edition (DRA). Available at: https://www.biblegateway.com/versions/Douay-Rheims-1899-American-Edition-DRA-Bible/

Thomas Aquinas. Commentary on the Nicomachean Ethics. Book V. Available at: https://isidore.co/aquinas/english/Ethics.htm

Thomas Aquinas. Summa Theologiae. Available at:

https://www.documentacatholicaomnia.eu/03d/12251274, Thomas Aquinas, Summa Theologiae \%5B1\%5D, EN.pdf

Vašek, B. (1931). Křest’anská sociologie, dil II. Spravedlnost v životě hospodářském. Spisy Cyrilometodějské bohoslovecké fakulty v Olomouci, 1931. Available at: http://librinostri.catholica.cz/download/VasKresSociol2-150dpi.pdf

Vodička, T. (1946). Principy sociální ethiky. Část IV-VI. Krystal, 1946. Available at: http://librinostri.catholica.cz/download/VodickaPrincipyMiklikPraconi-150dpi.pdf

Vřeštál, A. (1916). Katolická mravouka. Díl II. Podrobný. Část 2. Dědictví svatého Prokopa, 1916. Available at: http://librinostri.catholica.cz/download/VrestalPodrobne2-OCR.pdf

Woods, T. E. (2007). The unanswered questions of the just wage. In: Booth, P. (ed.).(2007). Catholic Social Teaching and the Market Economy. Institute of Economic Affairs, 2014. ISBN 978-085439-837-9. 144-169.

Worland, S. T. (1981). Exploitative Capitalism: The Natural-Law Perspective. Social Research, Summer 1981, Vol. 48, No. 2, 277-305.

Worland, S. T. (2001). Just Wages. First Things, February 2001, 110, 14-17.

Yuengert, A. M. (1996). Free Markets and Character. Catholic Social Science Review, 1.1 (Fall), 99110. https://doi.org/10.5840/cssr1996114 